Celtic: A Journal of Culture, English Language Teaching, Literature and Linguistics

Vol. 7, No. 1, June 2020.

E-ISSN: 2621-9158 P-ISSN:2356-0401

http://ejournal.umm.ac.id/index.php/celtic/index

\title{
ACADEMIC CULTURE BARRIERS FACED BY ENGLISH DEPARTMENT STUDENTS JOINING INTERNATIONAL INTERNSHIP PROGRAM
}

\author{
${ }^{1}$ Wulan Ramadhani, ${ }^{1}$ Dwi Poedjiastutie* \\ ${ }^{1}$ Universitas Muhammadiyah Malang, Indonesia \\ *Corresponding Author: Dwi_p@umm.ac.id
}

\begin{abstract}
Academic culture barrier is one of the barriers that students faced when they were going abroad whether for studying or doing their internship. There are lots of students' encounters a problem when they were doing their internship. This research was conducted to examine the academic culture barriers faced by ELED students joining the international internship program to Thailand. In conducting the research, the researcher utilized the descriptive qualitative design to obtaining formation related to the problem in academic life. The participants of this study were eight students of ELED UMM who join the international internship program in Thailand 2018. The researcher used semi-structured interviews and open-ended questionnaire in order not to limit participants in telling their experience. The results of this study are divided into 3 categories which are academic problems, solutions, and academic differences. The academic problems that the participants faced involve language, English knowledge, the use of Thai letters, curriculum, and students' participation. The solution that they gave were using gesture in dealing with the language problem, using role-play in dealing with lack of knowledge in English, teach the students alphabet in dealing with the using of Thai letters, designing their own material in dealing with no exact curriculum, and try to interact to the students outside the class in dealing with passive students participation. Furthermore, the academic differences are the relationship between student and teacher, and school culture.
\end{abstract}

Key words: Academic Barrier; Culture; Culture Barrier

\begin{abstract}
ABSTRAK
Academic culture barrier adalah salah satu hambatan siswa ketika mereka pergi ke luar negeri untuk belajar maupun untuk melaksanakan kegiatan magang. Banyak siswa mengalami masalah ketika mereka melakukan kegiatan magang. Penelitian ini bertujuan untuk meneliti hambatan akademik yang dialami oleh siswa pendidikan bahasa Inggris yang mengikuti kegiatan magang internasional di Thailand. Dalam penelitian ini, peneliti menggunakan deskriptif kualitatif desain untuk mendapatkan informasi yang sesuai dengan masalah yang dihadapi peserta magang khususnya dalam lingkungan akademik. Peserta pada penelitian ini adalah 8 siswa pendidikan bahasa Inggris yang telah selesai mengikuti magang internasional di Thailand. Peneliti menggunakan wawancara semi terstruktur dan kuesioner terbuka dengan tujuan untuk tidak membatasi peserta dalam menceritakan pengalamannya. Hasil dari penelitian ini terbagi dalam 3 kategori yaitu hambatan akademik, solusi dari hambatan akademik, dan perbedaan akademik. Hambatan akademik berupa bahasa, pengetahuan, penggunaaan huruf Thai, Kurikulum, dan partisipasi siswa. Solusi yang diberikan adalah menggunakan gesture untuk mengatasi hambatan bahasa, menggunakan role-play untuk mengatasi pengetahuan yang kurang, mengajar alphabet untuk mengurangi penggunaan huruf Thai, mendesain kurikulum sendiri untuk mengatasi masalah ketidakpastian kurikulum, dan lebih mendekati siswa yang kurang aktif untuk mengatasi masalah siswa yang pasif. Selanjutnya, perbedaan akademik berupa perbedaan hubungan siswa dan guru, dan perbedaan budaya sekolah antara Indonesia dan Thailand.
\end{abstract}


Ramadhani, W. \& Poedjiastutie, D. (2020). Academic Culture Barriers Faced by English Department Students Joining International Internship Program. Celtic: A Journal of Culture, English Language Teaching, Literature, \& Linguistics, 7(1), 83-93.

Kata kunci: Budaya; Hambatan Akademik; Hambatan Budaya

\section{INTRODUCTION}

Culture is a characteristic that is owned by each group. It is also a medium that unites one to another. As Hossain (2016) stated that culture is a condition where people have an ability to exist, think, feel, and relate others. Everyone have to know their culture in order to accept and to be accepted by others.

While going overseas, many new things can be found which are often different from the things that are in each home country such as food, cloths, language, religion, and etc. The different things found from the host countries are often unique because each culture gives the identity of the country. As Matsumoto (1996) cited in Spenceroatey (2012) said that culture is the sets of attitudes, values, beliefs, and behaviors shared by a group of people, but different for each other. Culture also attached to our body such as how we act, how we behave, how we talk and so on.

Studying in a new environment makes the people face a lot of challenges. Rawjee, et. al (2012) stated that it makes student face difficulties such as culture shock, language difficulties, homesickness, differences in the educational system, and loss of their established social network. Those challenges make people feel uncomfortable, disoriented, confused and anxious especially when they are in a new country which they had never visited before or it is called as cultural barrier.

Mirdehghan, et. al (2011) defines that cultural barriers are an obstacle in understanding different languages, spiritual beliefs, and social habits. The cultural barriers can occur in both social life and academic life. A research conducted by Poedjiastutie(2015) found that culture shock experienced by foreign students studied in Indonesia in social life are women-men relationship, different ways of thinking and different habits. While culture shocks experienced by foreign students in academic life are teacher's role and attitudes; the poorly organized programs; and the local students' attitudes. When students study overseas, there is a possibility that they will encounter a new education system. As Talebloo \& Bin Baki, (2013)mentioned that academic difficulties faced by international students refer to the academic system, teaching methodology, and faculty supervisor.

\section{Cultural Barrier}

Culture barrier is an obstruction experienced by an individual when they move to another place with a different atmosphere. As Veda \& Rani(2016) stated that culture barrier is the condition when people becoming aware in values, beliefs, and attitudes because of the different backgrounds. It mostly occurs to the international students who study and live outside of their native country or someone who travels abroad. In this study, the culture barrier means culture shock. The culture shock occurs when people feeling surprised or shock with what they are facing. As Cameron \& Kirkman(2010) defined that culture shock is a temporary phenomenological experience encountered by individuals because they find themselves unable to understand or convey their habit in a new culture. Culture shock is a common phenomenon when someone entering a new place they never visited before. It has been proved that anyone who enters a new environment will experience culture shock (Darío, et. al 2013). It depends on various factors which cause the extent of the culture shock: 
Celtic: A Journal of Culture, English Language Teaching, Literature and Linguistics

Vol. 7, No. 1, June 2020.

E-ISSN: 2621-9158 P-ISSN:2356-0401

http://ejournal.umm.ac.id/index.php/celtic/index

1. The intercultural experience we have had in the past: when we have the experience to travel to a new place, it easier to adapt to a new culture we are in. However, when we have no experience at all, we will be exposed to suffer culture shock.

2. Knowledge: the more we know about the place and the people we are in, the easier it will be to understand the new culture we are in. The less we know about the place, the more we faced culture shock.

3. The linguistic ability: the higher level our foreign language ability, the less probable it will be for us to have misunderstandings.

4. Human values: when we have an attitude of tolerance and respect for others, the possibility of experiencing culture shock will decrease.

5. Personality: confident and sociable people will find it easier to establish new relationships with other people.

6. Similarities: the more similar our home culture with the culture we are in, the fewer we will be exposed the culture shock.

7. Geography and weather: the difference in location and weather of the new country with our home country influences our feelings to adjust it or not.

8. The situation in the new environment: are we incorporated into the new culture we are in? Are we still feeling homesickness to our home culture?

\section{Academic Barriers}

The cultural barrier that most people faced not only happened in social life, but also in academic life. In Addition, academic culture is the rules, norms, behavior patterns and facilities used by learners as a guide in academic activities that includes the perspective of academic, academic spirit, academic ethic and academic environment (Samrin, et. al 2018).

The previous research from Raktham (2015) examined about the Chinese students' feeling after interacting with the Thai social learning environment. The result showed that the Chinese students experienced the academic difficulties such as poor programs from the host university, the inferior teaching styles of Thai teacher, inappropriate learning materials and language difficulties. There is also some differences in academic culture. China has very large and crowded classes with the serious atmosphere, the teaching is teacher-centered, and the authoritative relationship between teacher and students. Otherwise, Thai has smaller classroom and the relaxed atmosphere, and a positive relationship between teacher and students because the teacher is friendlier than Chinese teacher. Moreover, in the class, Chinese students are individual, hardworking, competitive, and goal oriented while Thai students are grouporiented, humble, kind, and have a good manner.

Srisakda (2018) conducted a study to know the Vietnamese students' academic problem when they were studying in the higher education institution in Thailand and how they adjust it. The finding revealed that the academic difficulties faced are not proficient in the host language, insufficient learning skill, and difficult material. Those problems lead the students to the stress and poor academic performance. At the end, the Vietnamese students could adjust it by learning language, reviewing the lesson, and asking the academic support from the lecturer and Thai students because the support from the classmates played important role in adjusting the academic problem. 
Chen and Chen (2009) cited in Srisakda (2018) stated that even though academic system are similar across culture, there must be any differences. Even though China, Vietnam, and Thailand are in the same Asian Culture, there must any differences between them. It is in line with Tsang (2001) cited in Srisakda(2018) that stated the Chinese students from Tiongkok still need to adjust to the Singaporean institutional environment even their country are close in term of culture norms. It revealed that every place has their own identical culture as well as their academic culture. The differences could lead to the barrier because someone do not familiar with their host culture and they feel disturbed by it. Other example, Vietnamese students faced difficulties in the language, it is because Vietnam has different language with Thailand. Raktham (2015)also mentioned that Chinese students feel their Thai teacher has low skill in teaching compared to China teacher. It hampers them because they have to adjust with it.

One of the previous participants of international internship to Thailand admitted that there are different cultures in the academic environment between Thailand and Indonesia. According to them, one of the differences is in term of time. In Indonesia, the total time for studying in school between primary school, junior high school, and senior high school are different. While in Thailand, the total time in all school level for studying is similar. It starts at 7 am to $4 \mathrm{pm}$. Other differences are the way students shakes their hand with the teacher.

Based on the data above, the study is trying to dig out cultural barriers faced by students studying overseas. Therefore, the researcher interested to know what are the academic culture barriers faced by ELED students when they were joining the international internship program in Thailand.

According to the coordinator of the International Internship program to Thailand, this program is part of the third internship held by the Faculty of Teacher Training and Education. The faculty conducts the third internships both regular and international. The regular internship, students are still accompanied by the teacher in the implementation of their teaching or called guided teaching, while international internships students are more released or freed to teach or are called independent teaching. The international internship is collaboration between Faculty of Teacher Training and Education with the Muslim Education Development Association of Thailand (MEDAT). Since the collaboration between them is still ongoing, this research is expected to give information about the culture barrier especially in academic life faced by students doing the practice teaching in Thailand so that they may anticipate unwilling or unwanted situations.

\section{METHOD}

Descriptive qualitative is considered appropriate to get a clear information and understanding of the phenomenon being studied. Lambert \& Lambert (2012)stated that descriptive qualitative is helpful to gain a certain event in detail. Therefore, descriptive qualitative is used to answer research question and describes the academic culture barriers faced by ELED student joined international internship program to Thailand in 2018.

The participants of this study are 8 students of English Language Education Department (ELED) who have participated in the International Internship Program to 
Celtic: A Journal of Culture, English Language Teaching, Literature and Linguistics

Vol. 7, No. 1, June 2020.

E-ISSN: 2621-9158 P-ISSN:2356-0401

http://ejournal.umm.ac.id/index.php/celtic/index

Thailand in 2018. Those students were seconded from 4 provinces in Thailand which are; Songkhla, Satun, Bangkok, and Krabi. There are one male and seven females. A purposive sampling technique was employed in selecting the research participants. Purposive sampling is the techniques when the researcher purposely selected the individuals because they have the capacity to give the information needed by the researcher (Creswell, 2014). Therefore, those students were chosen as participants because they have information from the experience faced when they were conducting their internship program.

The researcher utilized semi-structured interview order to make the participants free to answer the question based on their own experiences. After answering the question, the researcher gave a follow up questions in order to explore deeper information. The purpose of the semi-structure interview is to get a detail information about the academic culture barrier faced by them. Each of the participants were interviewed around 60 minutes and the researcher recorded during the interview in order to make sure there would not be a missing information.

Questionnaire is the second instrument used by the researcher. Since the question involve the participants' experiences, the open-ended questionnaire is suitable to use because they could be free in expressing or describing their opinion. There would be eight participants who will answer the questionnaire. The questionnaire will be constructed based on the result of the interview and the questions will be deeper based on the result of it. The researcher would provide Google-docs to invite them to complete the questionnaire.

The data from the interview and questionnaire were analyzed using the same steps. First, the researcher read the transcription over and over to check whether there was any missing information or not. Then, the researcher analyzed the transcription by giving it a color-coding to determine the theme/problem that the participants faced. Each problem faced by the participants was given a different color. Last, the researcher classified the same answers based on the identical color of the participants' explanation.

\section{FINDINGS}

This study found that the academic culture which become a barrier for the participant of the international internship are the language used in school, the English knowledge of the students, the use of Thai letter, The students' participation. In addition, the academic culture which different from Indonesia are the relationship between students and teacher, and school environment or school culture.

\section{Language}

Language becomes the most difficult aspect that participants faced. It is because the participants do not know Thai language and the student do not know the Indonesian language as well. English as an International language should be one of the media of communication. However, the participants think that Thailand students hard to speak in English.

When they pronounce a word whether in English or Arabic when they recite holy Qur'an is hard to understand. Maybe because they have their Thai accent which influences how they pronounce a word. Sometimes, when I spoke in English, they did not understand what I'm saying $(\mathrm{FN})$. 
Not only their accent which influenced the students how to pronounce a word, but the participants also said that they speak purely in the Thai language which made them difficult to speak in English. Moreover, English is not their main language.

I also learn basic instruction in the Thai language because they speak purely in Thai (PC).

The different language makes them difficult to convey their material to the students when they were teaching. Those cases indicated that language becomes the most difficult thing that hamper the participants of the internship in doing their teaching activity. They should be given the Thai language lesson from the faculty or from the Thailand itself as maximum as possible. Even though there must be a language barrier, at least they know a basic language used in teaching and learning.

\section{English Knowledge}

Almost every country has provided knowledge about English to its students since they were a kid. It makes students have broader knowledge because they got it earlier. Thailand has also provided knowledge of English since childhood but in reality, their English is still low. Low English ability is the obstacle felt by the participants of the international internship to Thailand. According to them, high school students cannot even spell or read. Here some concern expressed in the interview:

I would say low. Even I taught at the senior high school level, they still hard to spell $a b c d$. They still influenced by their mother tongue (SN).

The same participants also confirmed it in the questionnaire below:

Yes. They are difficult in term of spelling a certain word (SN)

Another participant faced the same case, as expressed in the interview below:

The level of their English is lower than in Indonesia. Only one or two students who understand what I said. For example, when I taught in senior high school what I expect is they could speak, but the fact not (YI).

It happens to the high school students who should not have learned to read anymore. That case directed that their ability in English is low because their spelling influenced the other skills which are reading and speaking. When they cannot spell well, they certainly cannot read well. It also influenced their speaking because they cannot speak fluently as Widowati \& Kurniasih (2018) stated that students must be able to speak before read.

\section{The Use of Thai Letters}

The use of Thai letters very troublesome besides the language as a media of communication. Not every country has their specific letters. They mostly used alphabetic as an international letters that known by every people. However, some countries has their specific letters such as Japan with their Hiragana, Katakana and Kanji letters, China with their Hanzi letters and also Thailand. Students in Thailand used to write in Thai letters rather than an alphabet. Here some concern expressed in the questionnaire:

Yes. They use Thai letter. It is because they cannot spell a word in English. Maybe, when they cannot answer the question by English, they rather to write it in Thai (FN).

Another participant faced the same case: 
Celtic: A Journal of Culture, English Language Teaching, Literature and Linguistics

Vol. 7, No. 1, June 2020.

E-ISSN: 2621-9158 P-ISSN:2356-0401

http://ejournal.umm.ac.id/index.php/celtic/index

Yes, they use Thai letter. All their book are written in English (FJ).

As stated above, most of Thailand students use their own letters in their learning. They prefer to write in Thai letters because they used to it. However, the use of Thai letters hamper the participants of the internship in doing their teaching because they are hard in reading or scoring the assignments from the students. The book which fully written in Thai letters also bothers the participants of the internship to deliver the material.

\section{Students' Participation}

Students' participation is how well or how the students participate in their class. Every school must have the students who are active and the others who are not or can be called passive. The active or passive students could be seen from how often they rise their hand, how often they involved in the team work and how often they participated in the class. It is various as what the participants of the internship faced when they were teaching in Thailand.

Here some concerns expressed in the interview:

They feel shy when they want to convey something or answer the questions (YI).

Another participant faced the other case:

I also find difficulties to deal with the active students. They are so enthusiast because I'm a foreign teacher. It's hard to tell them not to be noisy (LW).

Many participants of the internship felt that their students are very active and some of them felt the other way. Not only passive students who become an obstacles to their teacher. Yet, students who are over active also become the obstacles because students are too enthusiast to learn so that the teacher is difficult to control it. It can be indicated that the student's participations are various depend on the school, the environment or how their teacher teaches them in the class.

\section{DISCUSSION}

From the findings above, some terms need to be considered. First is the language which not only becomes a medium of communication but also a characteristic of culture (Kumalasari \& Soeparto, 2015). The international student felt shocked in the language aspect because of the different usage of grammar, pronunciations, and vocabularies between English and other native languages (Fan, 2010). It supported the experience from the participants that they faced difficulties when their students speak purely in the Thai language. Also, the Thai students' accent is different and it influenced how they pronounce a word. Thus, the participants solve the language problem by using their gestures to communicate with them.

The second is the English knowledge. All the participants agreed that the knowledge of Thailand students' that they taught is low. For instance, the high school students found it hard to spell a b c d. It is supported Noom-ura(2013) which stated that another highly-rated problem from Thailand students is the insufficiency in the knowledge of the English language. Although secondary school students have studied English for about six years of primary school, their skills are still basic. Thus, the participants of the internship make a role-play to solve that problem. Role-play can be 
used to increase their interest in English because they are treated like they are playing while at the same time they are also learning.

The third is the use of Thai letters. Thep-Ackrapong (2005) cited in Watcharapunyawong \& Usaha(2013)points out, "English and Thai are different at all levels: pronunciation, word, grammar, and the text". Therefore, writing tasks is not easy for them because most of the Thai language systems are different from the English systems. It is proven by the participants who find it difficult to deal with the students who use Thai letters in their writing. Thus, the participants of the internship could solve that problem by teaching them how to write the alphabet.

The forth is the curriculum. The English teaching problem in Thailand one of which is the impracticality of the guidelines for managing activities (Noom-ura, 2013). Also, the teachers do not understand well about the details of the curriculum. It is proven by the participants of the internship that they find difficulties in teaching their students because there are no exact guidelines from the school. Thus, they solved that problem by making their material to be taught to the students. Making material could be one of the good solutions. However, if the participants do not know how the curriculum in the place where they do their internship or they do not have a main teacher who could give them feedback, their materials are still doubtful.

The fifth is the students' participation. Thailand students feel shy when they want to express or convey something. Shy is an eastern culture because they only speak when the teacher asks them. In the eastern country, the students only speak when they called upon by their teachers(Raymond \& Choon, 2017). Teachers are to be respected and treated as an expert. It is interesting because not only the passive students who become a barrier but also the active students. Active here means more into their overactive behavior which is noisy. It makes their teacher hard to control them and their teachers only let their students play. Another participant said that she tried to interact with their passive students outside the class. By approaching the students, it is expected that teaching and learning activities will run better.

There are also academic differences found. First is the relationship between students and teacher. The participants said that the students really respect their teacher even they got physical punishment. They also said that when the students go to school, they are under the responsibility of their teacher. It supported by Kang \& Chang (2016) who said that Eastern culture such as Taiwan, China Korea believe that teacher is more than just a lecturer because teacher has the moral role as a 'parent'. The Thailand students assume that their teacher is also their parents that they need to respect. Even they got the punishment, it showed that they did something wrong and their teacher did it because they love their students as the way their parents love their children. Physical punishment is not a taboo thing and it becomes a culture in Thailand. Otherwise, in Indonesia, when a student gets a punishment, the one who is definitely blamed is his teacher.

Second is the different in term of school culture. The International teachers commonly experience the different cultures in and out of their schools(Alban, 2013). It is the same with the participants of the internship who also experience cultural differences in schools where they do their internship. The differences involve the activities in school, the duration of school, the holiday, etc. That difference occurs because of a culture where every school must have its own culture. 
Celtic: A Journal of Culture, English Language Teaching, Literature and Linguistics

Vol. 7, No. 1, June 2020.

E-ISSN: 2621-9158 P-ISSN:2356-0401

http://ejournal.umm.ac.id/index.php/celtic/index

The socio culture is influenced the existence of the academic barrier because education cannot be separated with culture. Govea (2007) cited in Keumala, Samad, Samad, \& Rachmawaty(2019)) stated that the academic barriers found are come from the cultural background which divided into collectivistic culture and individualistic culture. For example, in the collectivistic culture, individual students intervene in class only when called upon personally by the teacher. It is in line with the passive students' participation where the students only speak when they called by the teacher. It revealed that those barriers found are influenced by the cultural background which is the collectivistic culture as Darwish \& Huber(2003) stated that Asian more emphasized in the collectivistic culture.

\section{CONCLUSION}

This study reinforced our doubt about the preparation of the internship program. The barriers found are indicated that there is no maximum preparation before going to Thailand or the faculty had not been ready yet to send their students to teach in Thailand. Moreover, the data available in this study are taken from the students who already conducted their internship in South Thailand. Since the data gained from the south of Thailand, we cannot generalize that all Thai students have the same character. Also, we cannot generalize the participants of internship in Thailand in general will experience the same thing that is experienced by the participants of internship in Thailand especially the southern part. Thus, the conclusions present new hypothesis which can be further investigated.

\section{REFERENCES}

Alban, D. J. (2013). Cultural Adaptations of American Teachers in International Schools. Dissertations, 193.

Cameron, H., \& Kirkman, C. (2010). Managing culture shock for First Year International students entering Australian universities Managing culture shock for First Year International students entering Australian universities. 1995, 1-5.

Creswell, J. W. (2014). Research Design Qualitative, Quantitative, and Mix Methods Approaches.

Darío, R., López, A., \& Peña, D. (2013). Culture shock adaptation strategies. Revista Nebrija de Linguistica Aplicada.

Darwish, A. F. E., \& Huber, G. L. (2003). Individualism vs. Collectivism in Different Cultures: A cross-cultural study. Intercultural Education, 14(1). https://doi.org/10.1080/1467598032000044647

Fan, S. (2010). Language Shock: A Challenge to Language Learning. The International Journal - Language Society and Culture, 31, 42-51.

Hossain, M. (2016). English Literature and Language Review Cultural Barrier in Learning a Foreign or Second Language : An Outline and Clarification in Context of Bangladesh. 2(6), 65-70.

Kang, H., \& Chang, B. (2016). Examining Culture' s Impact on the Learning Behaviors of International Students from Confucius Culture Studying in Western Online Learning Context. Journal of International Students, 6(3), 779-797.

Keumala, M., Samad, N. M. A., Samad, I. A., \& Rachmawaty, N. (2019). The Influence of Socio Cultural and Educational Background on EFL Learners' Motivation. 
Ramadhani, W. \& Poedjiastutie, D. (2020). Academic Culture Barriers Faced by English Department Students Joining International Internship Program. Celtic: A Journal of Culture, English Language Teaching, Literature, \& Linguistics, 7(1), 83-93.

Indonesian TESOL Journal, 1, 1-88. https://doi.org/10.24256/itj.v1i1.556

Kumalasari, F., \& Soeparto, S. (2015). FACTORS INFLUENCING THE MOTIVATION OF THE STUDENTS FROM THAILAND IN CHOOSING ENGLISH DEPARTMENT IN UNIVERSITY OF MUHAMMADIYAH MALANG. A Journal of Culture English Language Teaching Literature \& Linguistics, 2(3), 45-50.

Lambert, V. A., \& Lambert, C. E. (2012). Editorial : Qualitative Descriptive Research : An Acceptable Design. Pacific Rim International Journal of Nursing Research, 16(4), 255-256.

Mirdehghan, M., Kargar, N. H., Navab, S., \& Mahmoodi, T. (2011). Cultural Barriers : Pros and Cons on ELT in Iran. International Journal of English Linguistics, 1(1), 15-20.

Noom-ura, S. (2013). English-Teaching Problems in Thailand and Thai Teachers ' Professional Development Needs. English Language Teaching, 6(11), 139-147. https://doi.org/10.5539/elt.v6n11p139

Poedjiastutie, D. (2015). Culture Shock Experienced By Foreign Students Studying At Indonesian Universities. TEFLIN Journal, 20(1), 25-36. https://doi.org/10.15639/TEFLINJOURNAL.V20I1/25-36

Raktham, C. (2015). Academic and Socio-cultural Adjustment of Chinese Exchange Students Studying in Thailand. 2nd International Conference on Language, Literature, and Cultural Studies, August, 137-151.

Rawjee, V. ., Reddy, K., \& Maharaj, M. (2012). EXCHANGE STUDENTS COMMUNICATION CHALLENGES: A CASE STUDY OF A UNIVERSITY IN SOUTH AFRICA. International Conference on Commuication, Media, Technology and Design, May, 198-203.

Raymond, C. Y., \& Choon, T. (2017). Understanding Asian Students Learning Styles, Cultural Influence and Learning Strategies. Journal of Education \& Social Policy, 7(1), 194-210.

Samrin, Hidayat, M. S. H., \& Rahmadanti, A. D. (2018). The Comparison of School' s Academic Culture Between Indonesia and Thailand. IOP Conference Series: Earth and Environmental Science. https://doi.org/10.1088/1755-1315/175/1/012160

Spencer-oatey, H. (2012). What is Culture ? A compilation of Quotations. GlobalPAD Core Concepts.

Srisakda, N. (2018). A Study of International Vietnamese Undergraduate Students' Psychological, Sociocultural and Academic Adaptation and Adjustment At A Higher Education Institution in Thailand (Issue August).

Talebloo, B., \& Bin Baki, R. (2013). Challenges Faced by International Postgraduate Students during their First Year of Studies. International Journal of Humanities and Social Science, 3(13), 138-144. www.ijhssnet.com

Veda, S., \& Rani, K. U. (2016). COMMUNICATION BARRIERS. Journal of English Language and Literature (JOELL), June.

Watcharapunyawong, S., \& Usaha, S. (2013). Thai EFL Students 'Writing Errors in Different Text Types: The Interference of the First Language. English Language Teaching, 6(1), 67-78. https://doi.org/10.5539/elt.v6n1p67

Widowati, D. R., \& Kurniasih, K. (2018). Critical Reading Skill and Its Implication To Speaking Ability in Multicultural Classroom. A Journal of Culture English 
Celtic: A Journal of Culture, English Language Teaching, Literature and Linguistics Vol. 7, No. 1, June 2020.

E-ISSN: 2621-9158 P-ISSN:2356-0401

http://ejournal.umm.ac.id/index.php/celtic/index

Language Teaching Literature \& Linguistics, $\quad 5(2), \quad 18$. https://doi.org/10.22219/celticumm.vol5.no2.18-23 